\title{
The land use rights accounting change led by real estate business tax to value-added tax and its impact
}

\author{
Zhirong Shen, Yingyu Chen \\ School of economics and management, Jiangsu University of Science and Technology, Zhenjiang \\ Jiangsu, 212003,China
}

Keywords: Business tax to value-added tax, Land use rights, Accounting.

\begin{abstract}
From May 1, 2016, the real estate industry has become a new area for China's fully implementation of "business tax to value-added tax". The sales tax to a value-added tax as the price of foreign tax changes as the price of the tax, both to reduce the tax burden on real estate development enterprises, reducing its cost of land development, but also affected the acquirer enterprises to obtain the cost of land use rights to develop products pay, thus making these companies produce the relevant accounting change and the resulting impact on the relevant financial statements and accounting elements enterprises.
\end{abstract}

\section{Introduction}

Mainly engaged in the business of real estate land use rights development and transfer, real estate development and sales and leasing agent construction and housing projects, the results of these business activities is to develop projects completed sale or transferred to the hands of those who need, in obtaining transfer income, and real estate development enterprises also need to pay sales tax in accordance with a certain percentage of their income earning. May 1, 2016 of a comprehensive business tax reform VAT pilot pushed to the real estate industry has brought significant tax changes. Accordance with the "value-added tax levy business tax reform pilot implementation" (Cai Shui [2016] No. 36) provides that, in the territory of People's Republic of China sales service, intangible assets or real estate units and individuals, as VAT taxpayers, should pay the value-added in accordance with the Implementation Measures tax. Thus, the real estate development enterprises in the general taxpayer will be levied 11\% VAT, and self-added tax invoices issued. Faced with this from the sales tax to a VAT tax included in price as the price of foreign tax changes, the implementation of real estate "Business tax to VAT", not only can reduce the tax burden of their own development, beneficial to the long-term development, but also to benefit to those who obtain their development projects from the development of the enterprise business. Real estate "Business tax to VAT" accounting of these companies will bring change, and thus have any effect on the accounting elements, leading to what changes have provided information about corporate financial statements, it is worth studying. Therefore, this article from the real estate development enterprises to develop land-use right to start the project, the implementation of real estate "Business tax to VAT" before and after the purchase of land use rights related to the impact of business conduct comparative analysis and study.

\section{Change of bought land use rights accounting before and after business tax to VAT}

From development companies purchase their land development project completion is an important way of enterprises to obtain land use rights. Press the "Enterprise Accounting Standards No. 6 Intangible Assets" provides the application guidelines, land use rights of the enterprises generally recognized as an intangible asset and initially measured at cost. Before the implementation of "Business tax to VAT," the development of enterprises occurs when paid transfer of land use rights behavior, you need 5\% of the actual transfer of income to pay sales tax, which is part of the sales tax as the price of the tax was included in the acquirer business purchase of land use rights costs, enter 
the value of its intangible assets in. In implementation of "Business tax to VAT", the transfer of land use rights paid VAT behavior, companies need to follow to obtain $11 \%$ of the total price and additional fees to pay VAT, as VAT price of foreign tax that part of the tax and do not enter the value of intangible assets of the purchaser, but included in the VAT input tax.

For example, a company from a development company purchased the land use rights for the new plant, which is expected to land use right transfer price of 114 million, it is expected amortization period of 10 years, according to the average number of years amortization. Two years later, companies abandoned the plant construction plan, and the transfer of the land use right transfer price of 134 million yuan. Without considering the impact of taxes and other factors, combined with the real estate industry, "Business tax to VAT" before and after the change in tax policy, corporate purchaser in the land use right, hold until the disposal of business accounting changes are as follows:

In the pre-implementation "Business tax to VAT" due to the development of enterprises need to transfer $5 \%$ of income to pay sales tax, to guarantee the transfer of 1.14 million actually receive income, the land use rights calculate and determine pricing $=114 \div(1-5 \%)=120$ million, or 1.2 million yuan to purchase enterprise is required to pay the transfer price, and therefore, the initial book value of land use rights of 120 million. Average life method, at the end of each year for an amortization of land use rights fee of $\$ 120,000$. 2 years after the transfer, the transfer price of 1.34 million yuan enterprise basis having $5 \%$ to pay sales tax, after deducting this time carrying residual value of land use rights, the final transfer of profits $=134-134 \times 5 \%-(120-2 \times 12)=313,000$ yuan.

In implementation of "Business tax to VAT", the development of enterprises in accordance with the transfer price of $11 \%$ subject to VAT, the VAT tax is out of the money, the development of business tax passed without consideration, the pricing of land use rights is directly determined to 1.14 million yuan, but the companies at the same time pay the transfer price of 1.14 million yuan, 125,400 yuan need to pay VAT. Thereafter, according to the average number of years, at the end of each year for an amortization of land use rights fee of 114,000 yuan. 2 years after the transfer, the transfer of enterprises to obtain income of 1.34 million yuan, while the charge output VAT 147400 transfer price by $11 \%$, ad valorem tax amounted to 1.4874 million yuan, due to the VAT tax is out of the money, by the purchaser shall bear, therefore, the transfer price after deducting the residual value of land use rights of the book after the transfer of profits $=134-(114-2 \times 11.4)=42.8$ million.

"Business tax to VAT" specific accounting results before and after the relevant business in Table 1 below.

Table 1. Change of bought land use rights accounting before and after business tax to VAT

\begin{tabular}{|c|c|c|}
\hline Business timing & $\begin{array}{c}\text { Accounting before business tax to } \\
\text { VAT } \\
\text { (Unit: } 10 \mathrm{k} \text { CNY) }\end{array}$ & $\begin{array}{l}\text { Accounting after business tax to VAT } \\
\text { (Unit: } 10 \mathrm{k} \text { CNY) }\end{array}$ \\
\hline Buying date & $\begin{array}{l}\text { Debt: intangible assets - land use } \\
\text { rights } 120 \\
\text { Credit: deposit in bank } \quad 120\end{array}$ & $\begin{array}{l}\text { Debt: intangible assets - land use rights } 114.00 \\
\text { Tax payable_-value added tax payable } \\
\text { (input tax) } 12.54\end{array}$ \\
\hline $\begin{array}{l}\text { End of 1st year } \\
\text { amortization day }\end{array}$ & $\begin{array}{l}\text { Debt: management charge } 12 \\
\text { Credit: accumulated amortization } \\
12\end{array}$ & $\begin{array}{l}\text { Debt: management charge } \\
\text { Credit: accumulated amortization } \\
11.4\end{array}$ \\
\hline $\begin{array}{l}\text { End of 2nd year } \\
\text { amortization day }\end{array}$ & $\begin{array}{c}\text { Debt: management charge } 12 \\
\text { Credit: accumulated amortization } \\
12 \\
\end{array}$ & $\begin{array}{c}\text { Debt: management charge } \\
\text { Credit: accumulated amortization } \\
11.4\end{array}$ \\
\hline $\begin{array}{c}\text { Transferring Day after two } \\
\text { years }\end{array}$ & $\begin{array}{l}\text { Debt: deposit in bank } 134 \\
\text { accumulated amortization } \\
24 \\
\text { Credit: intangible assets - land } \\
\text { use rights } 120 \\
\text { Tax payable - business tax } \\
\text { payable } 6.7 \\
\text { nonbusiness income } \\
\text { nat.3 }\end{array}$ & \begin{tabular}{cc} 
Debt: deposit in bank & 148.74 \\
accumulated amortization & 22.80 \\
Credit: intangible assets - land use rights \\
114 \\
\multicolumn{3}{c}{ Tax payable - value added tax payable } \\
(output tax) 14.74 \\
\multicolumn{2}{c}{ nonbusiness income }
\end{tabular} \\
\hline
\end{tabular}




\section{Change of accounting before and after business tax to VAT and its impact on accounting elements}

Compare "Business tax to VAT" before and after the change in accounting results found in the acquisition, holding and disposal of a series of business sectors, the real estate industry, "Business tax to VAT" will purchase the assets, liabilities and profit and loss accounting of land use rights of enterprises elements with a corresponding impact.

\section{Changes affect the time of acquisition}

Date of acquisition of land use right, the enterprise "Intangible assets - land use right" book value in "Business tax to VAT" after reduced. This is because, in the implementation of "Business tax to VAT" before the sales tax transfer of land use rights need to be borne by the transferor, the development company to achieve its expected transfer income will be tax passed, the sales tax applied to your transfer price. As examples, the expected transfer of land use right price was 114 million, since the other $5 \%$ sales tax to be paid, for the development of enterprises will transfer the price increase to 120 million, net of its commitment to the sales tax of 6 million, that is, receive 1.14 million yuan of transfer income. The implementation of "Business tax to VAT", the VAT borne by the purchaser enterprise, development enterprise without the tax passed, the purchaser enterprise directly purchase land use right transfer price as expected. Therefore, compared to "Intangible assets - land use right," the recorded value of 60,000 yuan a small part of the business tax. However, companies need to pay an additional 11\% of the input tax, input tax can be deducted debit "Taxes payable" liability account, no recorded value of the assets, but it will lead to increase their settlement funds.

\section{Changes affect the holding period}

"Business tax to VAT", the companies holding land use right amortization expense for each accounting period reduces the burden. This is due to the "Business tax to VAT" reducing land use right after the initial measurement of the cost of business at the balance sheet date when the value of the amortization of intangible assets, amortization expense will be reduced, thereby reducing the cost burden during each period. As shown in Example, "Business tax to VAT" initial entry value of land use rights of enterprises decreased by 6 million, compared to before amortization of $\$ 120,000$ per year, "Business tax to VAT" after the annual amortization expenses 114000 yuan, a decrease of 0.6 million.

\section{Change impacts at disposal.}

Disposal of land use right, "Business tax to VAT" before and after the transfer of the profits of enterprises were quite different. In implementation of "Business tax to VAT" front, the transferor should bear the transfer income of 5\% sales tax, this part of the business tax deducted directly from the transfer of profits. The implementation of "Business tax to VAT", the transfer of income at the same time charged to the purchaser of the business also charged output VAT, and therefore, the transfer of income enterprises to obtain the right to deduct the book value of the land use after the transfer of profits. As shown in Example, "Business tax to VAT" before and after the transfer of corporate profits 115,000 yuan difference, which causes the amortized cost value of the difference between the initial measurement of 4.8 million and is not subject to business tax 67,000 yuan.

\section{Change of accounting before and after business tax to VAT and its impact on financial statement}

With the implementation of real estate industry business tax to VAT, the relevant accounting results accounting changes, these changes will eventually be reflected in the financial statements. From the balance sheet, the amount of liquid assets in Central Africa project assets decreased, because the elimination of the development companies will be passed on to the land use right transfer price in the 
sales tax, making the acquisition cost of intangible assets is reduced; in liabilities current liabilities due to the amount of deductible input VAT effect is reduced, relative to offset the effect of stock-type mobile input tax assets generated, since the intangible value-added tax chain for much longer, sales items disposal of intangible tax is to appear, and on the general business, the disposal of land use rights will usually be many years or until the liquidation of the enterprise, and therefore input tax credits generated when the effect is more on the purchase of intangible assets advantageous enterprises. From the statement, the land use right fee expense items in each period to reduce the share of corporate pre-tax profits improved, but also lead to corporate income tax burden increased, but the increase in income tax expense only increased pretax profit $25 \%$ section, which is out of the pre-tax profit increased 75 per cent owned enterprises have to remain part of the results of the overall impact is still to enhance their overall profits. From the cash flow statement, the purchase of service occurs during investing activities Cash flow items purchased intangible assets in pay increases built. "Business tax to VAT" enterprises purchase price before the land use right to pass on payments contained in the sales tax part, which is about the expected rate of increase of tax transfer price of $5.26 \%$, that is $5 \% \div(1-5 \%)$, while "business tax to VAT" business after the purchase of land use right to pay value-added tax rate of $11 \%$, exceeding the sales tax rate of $5.74 \%$ tax. As shown in Example, "Business tax to VAT" enterprises after the date of acquisition to pay more than bank deposits, "Business tax to VAT" before more than 65,400 yuan, the difference formed is $5.74 \%$ portion 114 million. At the same time, as companies can be made only after the tax deduction VAT invoices, VAT invoices to obtain timely, we need to adopt the currency in the acquisition of funds for settlement, thus increasing cash flow expenditures. Although this part of the input tax credits through the current VAT payable way back, but not enough to offset the output tax if the current is transferred to the latter part, it will increase their current cash flow burden.

\section{Conclusions}

In short, the real estate industry, "Business tax to VAT" the industry is changing not only affect the level of their own tax and accounting content for their business accounting and tax burden generated demand-side business enterprises has also brought changes and produced Tremendous influence. The implementation of "Business tax to VAT", the reduced cost of the demand side of business investment in the land use right of assets project, eliminating the business tax burden, increasing the scope of VAT deduction, thus effectively reducing the tax burden on enterprises, help to improve the business financial condition, improve business results. In the long run, it will help enhance the enterprises to expand business scale of confidence and ability. It must also be clear that the VAT deduction need to obtain value-added tax as a precondition, which requires the purchaser to pay timely completion of business activities. Therefore, before the purchaser enterprises in the acquisition of land use rights shall arrange financial payment plan to ensure the successful completion of the payment activities, otherwise it will be difficult to achieve, "Business tax to VAT" after brings tax advantages.

\section{References}

[1] State Administration of Taxation. Levy Interim Measures of real estate development business sales of self-developed real estate projects VAT.SAT Announcement No.18, 2016

[2] State Administration of Taxation. Business tax to value added tax trail implementation rules. Mar.23, 2016 